\title{
Punishment for Polygamy Doer in The Perspective of Islamic Law in Indonesia
}

\author{
Nurcahaya \\ Faculty at Tarbiyah and Education \\ UIN Sultan Syarif Kasim Riau \\ Indonesia \\ Syarif Hidayatullah State Islamic \\ University Jakarta, Indonesia \\ nurcahaya@uin-suska.ac.id
}

Nurrahmi Hayani

Faculty at Economic and Social

UIN Sultan Syarif Kasim Riau Indonesia

Syarif Hidayatullah State Islamic

University Jakarta, Indonesia

nurrahmihayani@uin-suska.ac.id

\author{
Srimurhayati \\ Faculty at Tarbiyah and Education \\ UIN Sultan Syarif Kasim Riau, \\ Indonesia \\ Syarif Hidayatullah State Islamic \\ University Jakarta, Indonesia \\ smurhayati@yahoo.com
}

\author{
Muhammad Absor \\ Ph.D Students (S3) \\ UIN Sultan Syarif Kasim Riau \\ Indonesia \\ Syarif Hidayatullah State Islamic \\ University Jakarta, Indonesia \\ absormuhammadeuin-suska.ac.id
}

\begin{abstract}
This paper explores the Indonesian regulation on polygamy for government officers. Some regulations have formally issued and amended in terms of issues on polygamy; regulation number 45 in 1990 is specially regulated polygamy doer to get permission for marriage and divorce. Hence, aims of this paper are to find out what punishments are given for civil servants doing polygamy in terms of Indonesian regulation and how the punishments given for civil servants in terms of Islamic Marriage Law/fiqh are. As a library research, the regulation number 45 in 1990 has been used as the data sources besides Holly Qur'an, Hadist, fiqh books and compilation of Islamic Laws. Thus, this research found out that civil servants who broke the polygamy law could be fined by mount of IDR 7500 and some other punishments if his new marriage had no consent from applied rules. Meanwhile, female civil servant whose status was as second, third, or forth wife would be ceased disrespectfully from her position as a civil servant. Secondly, in Islamic law or fiqh, polygamy is obligated to fulfill ascertain requirements. In sum, regulation also prohibited to do polygamy since its negative impacts (mafsadah) are bigger than positive one (mashlahah).
\end{abstract}

Keywords- Polygamy; Civil Servant; Fiqh; Indonesian Regulation; society

\section{INTRODUCTION}

Humankind's history has recorded tremendous events including ones' marriage, and there have been noted some problematic issues. One of them is the "Polygamy" or "ta" addud al-zaujat" [1]. In the past, many people were used to do polygamy before Islam came to their lives such as Ibranians, Arabians, Jahiliyah, and Cisilians [2, p. 9]. This issue in Islamic perspectives has been formally accepted, but in the implementation, this is still problematic among Muslims for some arguments, for example its normative laws, psychological aspects and even to gender issues. Western scholars claim that polygamy is the evidence of Islamic teaching to discredit and discriminate woman.

One of the causes is the emergence of instability of social lives dealing with her/his education levels and reasons for what they do polygamy. If the reasons of doing polygamy has been published and known broadly by public, and even it is formally stated and issued in formal regulations, academic research will have no debates on polygamy. This is also being applied to the ways of conducting polygamy since some people of polygamy doers have no understanding and do not implement its fundamental bases or principles of doing polygamy. Their minimal understanding will affect to social lives and their marriage.

In Indonesia, there has been an effort to minimize the activity of doing polygamy by issuing Indonesian Regulations, for instances the Regulation Number 1, 1974 about marriage, Number 9, 1975 about technical procedures of implementing regulation Number 1, 1974 about marriage. For Civil Servant/Government Officers, Indonesian Government has issued regulation Number 10, 1983 and has been amended Number 45, 1990 about permission to marry and divorce for civil servants. Then, Indonesian government has issued a special regulation for Moslem by President Number 1, 1991 about Islamic Law Compilation.

Some articles on regulation Number 1, 1974 about marriage and its implementation, and Islamic Law Compilation are principally in line with Islamic Law. According to the regulation, Indonesian government's law of marriage is "Monogamy" [3].

This statement is referred to al-Qur'an an-Nisa, 3: "And if you fear that you will not deal justly with the orphan girls, then marry those that please you of [other] women, two or three or four. But if you fear that you will not be just, then [marry only] one or those your right hand possesses. That is more suitable that you may not incline [to injustice]. Doing justice is to his wives in terms of her clothes, house, and mental and other physical needs). Before this verse came to Prophet Muhammad, verses on polygamy have been stated and implemented by previous prophets. This verse in Quran 3 limits to four wives only and his slaves. This will be close 
to do good deeds (Q.S. An-Nisa, 3 and Ministry of Religious Affairs, 2004, 24).

The above verse explains three main points. Firstly, people who are doubtful to do justice to his daughter's wealth and may not to marry her in terms of avoiding unfair to her wealth. Secondly, they should choose another woman either 2 or 3 even 4 women. Thirdly, if various regions.

The issue is also taking place in Indonesia. Polygamy is among debatable cases and becoming a controversial issue [2, p. 9]. In another view, polygamy has been introduced to public since its fundamental premises are becoming an alternative solution toward having an affair and engaging in a prostitution. However, if polygamy may not do justice to his wives, it is suggested to marry just one wife or marry his slave.

The implementation of Regulation No. 1, 1974 clearly states that man who marries to more than one wife must get permission from local court (article 4, passage 1) and his approval is given to him by fulfilling the following requirements:

1. A wife cannot do her roles and duties

2. A wife is suffered from physical problems

3. A wife cannot give a child (Regulation No. 11974 in 2007, 3)

Hence, for a civil servant - polygamy case - has been regulated by regulation No. 45, 1990 as the amendment of the regulation No. 10, 1983 about the permission to marry and divorce for civil servant. It is clearly stated on article 4 that:

1. Civil servant who marries to more than two wives must get the formal permission from local court.

2. Civil servant (woman) may not become the second/third or fourth wife.

3. The permission or approval must be in written form.

4. The permission as stated at point (3) must state logical reasons to do polygamy.

Regulation No. 1, 1974 seems to be contrary to the Islamic Law since it does not require the approval from the local court and there is no prohibition for woman to become the second/third or fourth wife. Thus, researcher is interested in studying this issue scientifically.

\section{METHOD}

This study was a library research. The main research questions are what punishments are given to civil servants doing polygamy based on regulation Number 1, 1974? and what punishments are given to civil servant doing polygamy based Islamic Law "fiqh"?. This method was to collect the written data by doing content analysis [4]. Then, the primary data used was Regulation Number 1, 1974. Meanwhile, for a civil servant was Regulation Number 10, 1983 which had been officially amended into Number 45 in 1990. Holly Qur'an, Hadist, fiqh book and Compilation of Islamic Law are becoming the second data/resources. In addition, the data were analyzed by using descriptive analyses. This aim to describe the true phenomena systematically and accurately as well as to find its relations to adherent issue [5].

\section{RESULT AND DISCUSSION}

\section{A. Polygamy}

A term "polygamy" is derived from a work "poly" means "several or many" and "gamy" means "wife". It means that polygamy is having several wives. Hence, it is defined as "a man (husband) marries to one and more wives" but it is limited to four wives [6]. In Arabic term, polygamy is called as ta"addud az-zaujaat [7]. Meanwhile, Indonesian Dictionary states that polygamy is the activity of a man marries to several wives in his life, [8]. In addition, Islamic dictionary states that polygamy is the condition of a man who marries to two till four wives [9].

Moslem scholars and some polygamy doers use Quranic verse on Surah an-Nisa"e, 3 which means that "And if you fear that you will not deal justly with the orphan girls, then marry those that please you of [other] women, two or three or four but if you fear that you will not be just, then [marry only] one or those your right hand possesses. That is more suitable that you may not incline [to injustice] (Q.S. AnNisa $\left.{ }^{e e}, 3\right)$. This verse is commenced by an alternative solution to orphans in form of directing to marry. But, if he is injustice to wives (orphans), he is instructed to marry other women and do them in justice. This verse is also related to activities of Islamic marriage that is limited to marry to four wives justly. Prophet Muhammad also stated that "Narrated from Salim, from his father Radliyallaahu'anhu that Ghalian Ibnu Salamah converted into Islam together with his ten wives. Then, Prophet Muhammad instructed to Sallam to choose four wives and divorced the rest;.the Hadits is form Imam Malik form Zuhri, Hadits Ghailan. (Syafie I, 1338 [274/1]). Another Hadist from Qais Ibnu Al-Harits narrated by Abu Daud and Ibnu Majah means that "from Qais Ibnu Al-Harits states that when he converted into Islam he has eight wives, and I met Muhammad and told about his family and Muhammad stated to "choose four among them". (H.R. Ibnu Majah). Ibnu Katsir in his interpretation mentions that prophet's companions who had four wives asked to divorce others and only four wives are allowed. This premise becomes the main concept in justifying Islamic law to marry only four wives [10].

The limitation to be married by a man will be another requirement that is to do fairly for his wives when doing polygamy. The verse is ended by highlighting the warning for him if he does injustice for his wives. In understanding a verse of polygamy, Imam Syafii, Hanafi, Maliki and Hambali argued that a husband may have more than one wife since Islamic Law allows him to marry until four women. But, this approval is required other requirements to do justly to his wives [11].

\section{B. Punishment for the Polygamy Doer}

The basic principle of marriage in Indonesia is 
monogamy. This statement is based on regulation (UU) No. 1, 1974. However, there is a chance to marry woman until four by means of getting approval from local court and his first wife's in advance. For a civil servant, he must fulfill other requirements based on Regulation (PP) No. 10, 1983 Article 10, passage 1; they are, (1) a wife cannot do her roles and duties; (2) a wife has physical problems and needs special treatments; (3) a wife cannot give a birth (UU no. 1 ,1974 Article 4 passage 2; PP No. 9, 1975 Passage 41 a; PP No. 10, 1983 Article 10 passage 2, and Compilation of Islamic Law, Article 57).

However, someone who wants to do polygamy must meet a cumulative requirements such as, (1) a written approval from his first wife; (2) a legal guarantee from husband to fulfill wife and children's basic needs; (3) a formal written guarantee to do fairly to his wives (UU no. 1, 1974 Article 5, PP No. 9, 1975). To prove his ability to cover all needs, he must get an official statement from his organization/office and signed by treasurer.

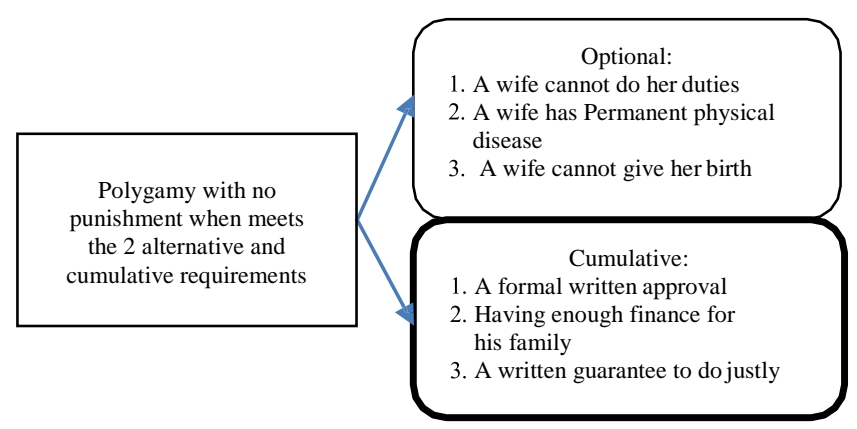

Someone who breaks the law of polygamy could be punished and fined with for seven thousand Indonesian Rupiah (IDR). This amount is seen in perspective of value not its amount. A civil servant who has more than one wives without any permission mentally and physically.

(4) to repeal his status disrespectfully as a civil servant (PP Number 30 Article 6 passage 4, 1980).

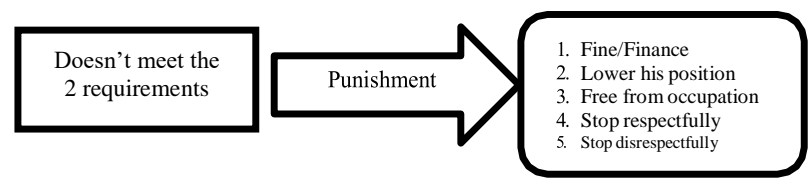

Woman civil servant who becomes the second, the third or the fourth wife will automatically be repealed her status as a civil servant (PP Number 45, 1990 Article 15 passage 2 and Article 4 passage 2).

The Indonesian constitution regulates a man who wishes to do polygamy by fulfilling the required requirements: (1) has ability to provide sufficient finance for his family; (2) has ability to do justice for all his wives. That is why the constitution tries to keep woman's right by getting her formal approval if his husband wishes to do polygamy as well as a written approval from the local court. And the Islamic local court has the authorities to reject or approve husband's proposal to do a polygamy.

Thus, Indonesian constitution on polygamy prohibits to husband to do polygamy even though the Al-Qur'an gives chance to do so. The prohibition is because of its prohibition (mafsadah) is higher than usefulness (mashlahah), [12]. The constitution is made to play a higher role than classical book of "fiqh."

One of the requirements to do polygamy is to do fairly to his wives. This is in line with qur'anic verse, "then marry those that please you of [other] women two or three or four", then this verse is interconnected to the next verse that is "but if you fear that you will not be fair, then [marry only] one or those your right hand possesses. That is more suitable that you may not incline [to injustice]." Doing polygamy, in another hand, is forbidden since its part of verse is taken from " $f i$ "il amr" which directs to answer the adherent verse "fa in khiftum an la ta "ulu". Thus, it can be drawn into "to marry one wife "or "to marry only one can be given punishments by four possibilities:

a. to lower his position level;

b. to free his position/job;

c. to cease his status as civil servant formally prior to his request;

The source of its prohibition is derived from the end of the verse "zalika adna an la ta "ulu". It means that doing polygamy is prohibited to avoid injustice or bad deeds. The law of doing polygamy for some scholars' views is "azimah, however others argue that it is allowed to do if he is able to fulfill all the requirements and i called as rukhshah [13, p. 88]. Ibrahim Hosen has scientifically studied a wide range of scholars' arguments on polygamy. Some of their arguments are to do fairly is not the main requirement as argued by some Quranic interpreters or mufastir, but it is viewed as Islam gives possibility to do polygamy. In terms of conceptual law, any law can be judged as the requirements are met.

An illustration of the concept can be seen in doing a worship which is obligated to take ablution before doing the worship. It means that both worship and ablution are the adherent two entities. Regarding to law of doing polygamy, doing a justice cannot be performed before doing polygamy. Therefore, do justly to wives cannot be argued as the law requirement, but doing a justice is regarded as Islamic requirement obligated to husband after his marriage. The law requirement affects the legal standing of doing polygamy. But this concept is not used for the Islamic law since someone who does polygamy injustice to his wives, will be burdened "sin" by God. If doing a justice becomes the requirement law in doing polygamy, the marriage will break the law because of his injustice to wives [13, p. 92].

\section{CONCLUSION}

Regarding to the analysis on the issue of polygamy and its punishments for civil servant in terms of Al-Qur'an Surah An- Nisa', 3 and Constitution Number 1, 1974, it is found that polygamy done by civil servant has been formally regulated on government regulation Number 45, 1990 and has been amended by Act Number 10, 1983 about the 
approval and divorce for civil servant. Article Number 4 is clearly stated that: (1) civil servant (man) who will marry to women must get the approval from the local court, (2) civil servant (woman) is not allowed to be the second/third/fourth wife, (3) the permission as stipulated on Article 3 must be in written form. On permission letter as stipulated on Article 1, it must be clearly stated the reasons of marriage. Then, Surah an-Nisa' 3, clearly states and uses "و which means "or" not "and". So, it limits to 4 (four) wife not more than that.

Regarding the analysis on the issue of polygamy and its punishments for civil servant in terms of Al-Qur'an Surah An-Nisa 3 and Constitution Number 1, 1974 found that polygamy done by civil servant has been formally regulated by government regulation Number 45, 1990 and has been amended by Act Number 10, 1983 about the approval and divorce for civil servant. Article Number 4 is clearly stated that: (1) woman". This is based on premise "instruct to do something is by leaving something". It is interpreted as "if you fear that you will not be fair, then [marry only] one". It must be clearly stated the reasons of marriage. Then, Surah an-Nisa' 3, states and uses " و " which means "or" not "and". So, it limits to 4 (four) wife not more than that. civil servant (man) who will marry to women must get the approval from the local court, (4) civil servant (woman) is not allowed to be the second/third/fourth wife, (3) the permission as stipulated on Article 3 must be in written form. On permission letter as stipulated on Article 1.

\section{REFERENCES}

[1] F. A. Kodir, Memilih Monogami; Pembacaan atas Al-Quran dan Hadist Nabi. Yogyakarta: Pustaka Pesantren, 2005, p. ix.

[2] S. Sabiq, in Fikih Sunnah, Jakarta: Pena Pundi Aksara, 2007.

[3] A. Manan, Aneka Masalah Hukum Perdata Islam di Indonesia. Jakarta: Kencana Prenada Media Group, 2008, p. 6.

[4] B. Ashshofa, Metode Penelitian Hukum. Jakarta: Renika Cipta, 2004, pp. 38-42.

[5] M. Nazir, Metode Penelitian. Jakarta: Ghalia Indonesia, 1999, p. 63.

[6] A. R. Ghozali, Fiqh Munakahat. Jakarta: Kencana Prenada Media Group, 2010, p. 129.

[7] R. Hakim, Hukum Perkawinan Islam. Bandung: Pustaka Setia, 1999, p. 13.

[8] Peter and Y. Salim, "Kamus Bahasa Indonesia Kontemporer." Modern English Press, Jakarta, 1991, p. 1178.

[9] Sudarsono, Kamus Agama Islam. Jakarta: Rineka Cipta, 1994, p. 180.

[10] I. Katsir, Tafsir Al-Qur'an 'Azim. An-Nasyr: Daar Linnasyri Wa atTauziie'i, Cet. II, 1999, p. 80.

[11] M. J. Mughniyah, Fiqih Lima Mazhab. Beirut: Dar al-Jawad, 2011, p. 109.

[12] M. A. Mudzhar, Fatwa-fatwa Majelis Ulama Indonesia Studi tentang Pemikiran Hukuman Islam di Indonesia 1975-1988. Jakarta: INIS, 1993, p. 100.

[13] I. Hosen, Fiqh Perbandingan dalam Masalah Nikah, Talak, Rujuk dan Hukum Kewarisan. Jakarta: Balai Penerbitan \& Perpustakaan Islam Jajasan Ihja' Ulumuddin Indonesia, 1971. 